\title{
History OF THE U.S. ACADEMIC OCEANOGRaphic Research FleEt And the Sources of Research Ships
}

\author{
By T.K. Treadwell, D.S. Gorsline and R. West
}

I N THIS ARTICLE WE SKETCH the evolution of the U.S. oceanographic fleet, concentrating on academic research vessels. We also discuss briefly the sources of research ships and their operational support: these factors seem especially pertinent in the context of our present aging and somewhat underutilized lleet.

\section{Early History}

Three agencies were the mainstays of U.S. marine science and the scientific fleet (including hydrographic surveying ships) prior to World War II: the Coast Survey, the Fish Commission, and the Navy Hydrographic Office (all these have undergone many changes of titles and activities; to avoid confusion. they will be referred to throughout by these original names). Until the creation of the National Science Foundation (NSF) in 1950, they carried out the vast bulk of our hydrography and oceanography.

Probably the first scientifically-used vessel was the Constitution - "Old Ironsides" - with which the Navy surveyed New London Harbor in 1811. The Coast Survey began surveys in 1834 in New York Harbor using freighters and schooners and, in 1838 , fielded the surveying ship Natilus. the first vessel built specifically for science at sea in this country.

The establishment shortly after the Civil War of the U.S. Fish Commission and of a separate Navy Hydrographic Office greatly expanded our seagoing scientific capability. The Hydrographic Otfice was created primarily to do surveys world wide and make charts, but it also looked at a variety of oceanographic problems, few of which are uniquely relevant to military matters. The Fish Commission was charged with finding out where all the fish had gone. but it too covered a broad spectrum of marine science. It also made maritime history in 1882 with dhatross, the first vessel constructed specifically for what we now think of as oceanography.

T.K. Traadwell. Department of Oceanography. Texal Ad,W University. College Station. TX 77843: D.S. Gorsline. Universty of Southern Calufornia. Geological Sciences Department. Low Angeler. CA yo089: and R. West. National Science Foundation. Ocean Sciences Division. 1800 G. Street, N.W.. Washington, D.C. 20550 .

Condensed from a longer report by the same authors published in $\overline{1} 988$.
Throughout the late 1800 s, the Coast Survey was active in coastal surveying. mostly using ships built for the purpose. The Hydrographic Office. on the contrary, never had much success in getting funds to build new ships but instead had to use converted, superannuated Navy ships. which were always abundant and free. Indeed, it was not until the 1960s that the Navy began designing new ships for surveying and oceanography.

Except for those of the "Big Three." there were very few sea-going scientific ships in the late 19th and early 20th centuries. The Carnegie Institution operated the Galilee, a general-purpose research vessel. from 1905 to 1908 , followed by their nonmagnetic hull Carncgie. Two Navy cruisers were detailed in 1912 to the International Ice Patrol, and. in the same time range. Alexander Agassiz was built in 1907 for the forerunner of Scripps Institution of Oceanography ( $\mathrm{SIO}$ ). Regrettably. a quarter-century would elapse before another would be built for research, the Allantis at Woods Hole Oceanographic Institution (WHOI).

\section{The Modern Research Fleet}

Turning to the relatively modern (post-1930) research fleet, there have been four distinct phases: Pre-World War II, World War II to 1960, 1960 to 1980 , and 1980 to present. All aspects of U.S. marine science. both academic and governmental. were shaped by powerful external forces during cach of these phases.

\section{Pre-World War II}

In 1930, there was a depressed economy and an attitude of isolationism. This environment not only kept the marine science community small hut also focused its interests primarily on coastal rather than global problems. The government research fleet was cut back, and many academic scientists had to depend on ships of opportunity. Fortunately, as early as 1927. the National Academy of Sciences began to take an interest in the subject: its Committee on Oceanography recommended the formation of several academic centers of marine research.

Triggered by this, grants from the Rockefeller Foundation established WHOI. expanded the laboratory at the University of Washington (UW). and 


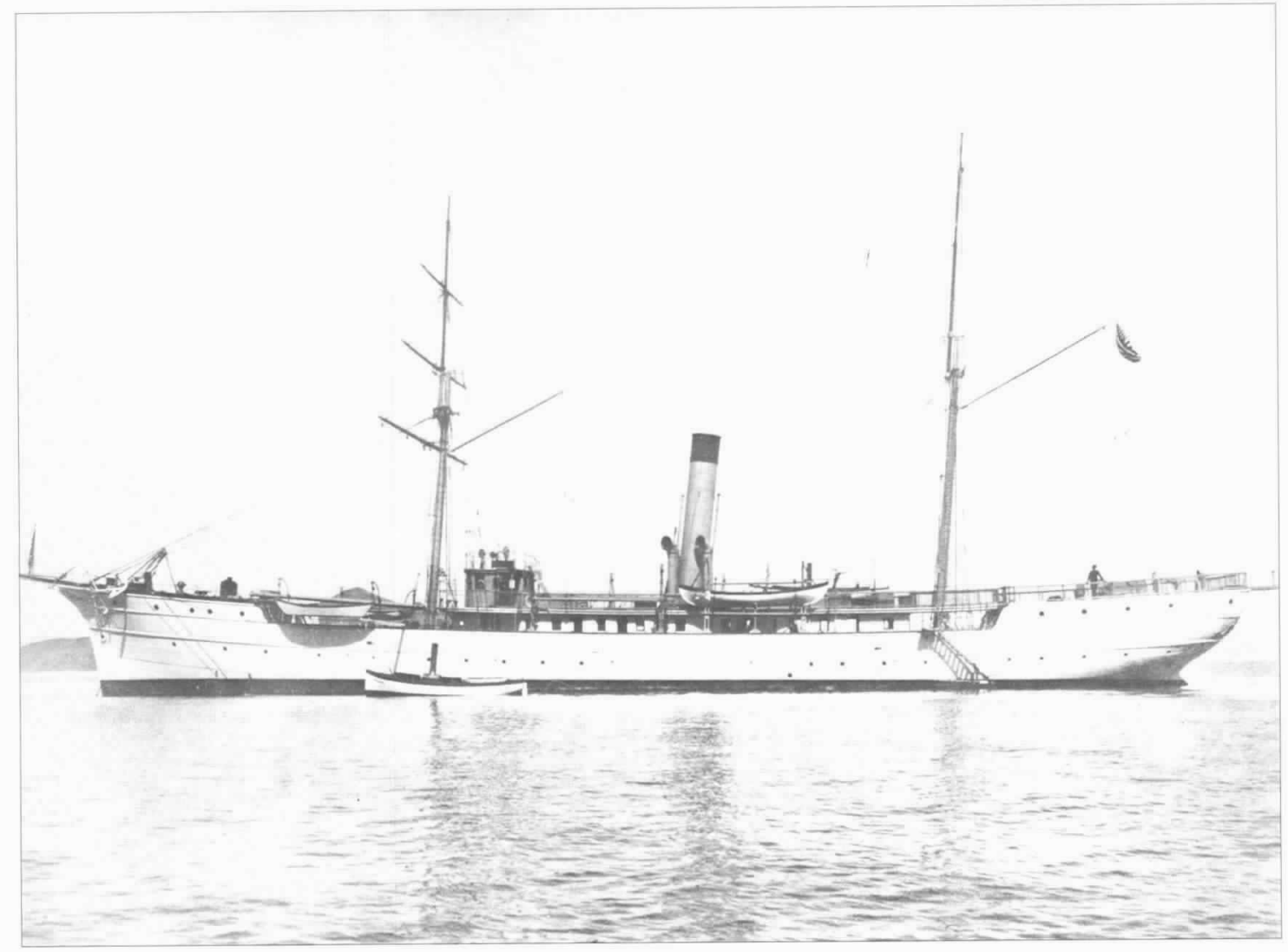

The steamer Albatross, built in 1882 for the U.S. Fish Commission, was the first U.S. ship designed explicitly for oceanographic research. Shown here in immaculate trim, she poses for posterity with foreyards squared away and a natty steam launch alongside. Perhaps the individual casually leaning on the quarterdeck rail is her first commander, Zera L. Tanner, who supervised the vessel's construction and directed her operation for the first twelve years of service. The iron-hull, twin-screw Albatross was 234 feet $(71 \mathrm{~m})$ in overall length, and she displaced 1,074 tons, making her a large research vessel even by today's standards. She could be technically classified as a steam-auxiliary sailing vessel, but it is apparent from her rig, which lacks main and fore booms, that she was never expected to be efficient under sail, at least not to windward. The spindly spars extending aft from the masts appear suitable only for light lifting or signalling, and not for service as gaffs to support sails. There is no evidence of a sounding winch or a hydrographic platform, but these probably were mounted on the starboard side, out of view in the photo. On the other hand, the vessel's fantail supports a substantial platform that must have been an exciting place to work in rough seas. DAB

Photo courtesy of The Mariners' Museum (Newport News, Virginia), The Stewart Nelson Collection; photo originally published in Nelson (1971).

contributed to SIO. Captain G. Alan Hancock had been providing assistance to marine research at the University of Southern California (USC) and continued to do so. As a result of these actions, all supported exclusively by private funds, four major oceanographic institutions emerged in the 1930s.

Each institution had a ship. The 145' Atlantis was built for WHOI with Rockefeller Foundation funds; SIO acquired the 104' E.W. Scripps, an ex-yacht donated by the Scripps family to replace a small purse-seiner which it had been using; UW acquired the 75' Catalyst with Rockefeller funds; Captain
Hancock donated the Velero III, a 240' yacht, to USC. During this period, the federal fleet only acquired five new ships, and this was more than offset by retirements of others. In sum, the academic fleet just prior to World War II consisted of only five ships, and the federal fleet consisted of little more than twice that number.

\section{World War II to 1960}

World War II threw the US into global affairs, and many sea campaigns not only drew public interest to the ocean but highlighted our ignorance of it. Academic ships, as well as those of the Coast Survey and 
By 1953.

the academic fleet

contained twenty-three

ships. government fisheries research, were put to work on Navy research or surveying tasks. Most of the small marine science community turned to military-oriented work, either in uniform, the civil service, or at their home institutions. The Navy needed, and got, oceanographic help in everything from submarine warfare to amphibious landings. While this assistance certainly contributed to winning the war. even more importantly it impressed on the nation that science was not an abstract, useless endeavor, but could contribute to the public good in many fields.

This led to the formation immediately after the war of the Office of Naval Research (ONR) and, in 1950. of NSF. which were both dedicated primarily to the support of research in the academic community. With financial backing from ONR. the existing marine research centers were expanded, and a number of new ones created, each with a ship provided by the federal government. Because of the urgency, and the availability of free surplus ships left over from the war. practically all of these were converted hulls. such as the tug Horizon at SIO, the salvage ship Chain at WHOI, and the minesweeper Hidalgo at Texas A\&M University (TAMU). Note particularly that this academic expansion was financed largely by the federal government. a reversal form the pre-war period in which private support totally dominated.

Activities in the federal agencies paralleled this academic expansion. The Navy Hydrographic Office started a major oceanographic program. in addition to its traditional charting, and converted a number of ships. Typical were the Tanner class (ex-troop transports) and the Harkness class (ex-minesweepers) for surveying. and the Sam Pablo class (ex-seaplane tenders) for oceanography. The Coast Survey ships which had been diverted to military-oriented charting reverted to their parent agency which began to expand its program of oceanographic research. The same was true of fisheries studies, and both groups began acquiring more research ships primarily through new construction.

By 1953, the academic fleet contained twentythree ships, tabulated by Treadwell, et al. (1988). At this time, the federal fleet was somewhat larger with about thirty-two ships, of which about half were owned by the Navy, a third by the Coast Survey. and the remainder was dedicated to fisheries and other specialized work.

Several things are striking about this motley fleet which appeared so quickly. One is that the academic ships were of modest size. With the exception of l'ma at 202'. the "big ships" were only in the 140' range: the majority of the fleet was under $1000^{\prime}$. The second is that most ships, both academic and federal. were conversions. And third, in spite of the great increase in federal funding for marine science, over hall of the academic ships at mid-period had been acquired with private money.

Perhaps most surprising is that in spite of their widely diverse original hull types. the conversions are generally remembered as being entirely adequate for research work. While some of this feeling may be due to the glow of nostalgia and the need to make do with what was available, a research fleet, spread around the country, did come into existence quickly and cheaply, providing the platforms for tremendous growth in marine science.

\section{0 to 1980}

As a general framework. this post-war and postSputnik period was marked by a national awareness of the rest of the world and an intense interest in science. These factors fostered international cooperation in research, strongly tempered with a desire to achieve world leadership. In marine science, interests expanded from our coastlines to global scales. leading to such major programs as the International Geophysical Year, the Deep-Sea Drilling Program, the International Decade of Ocean Exploration, and the Global Atmospheric Research Program. Specialized federal programs, particularly in the Navy and in fisheries research, broadened similarly.

This burgeoning activity was carried out on a fleet which at its peak. toward the latter part of the period. totalled over 590 ships, about equally divided between academic institutions and federal agencies. In contrast to the hasty post-war expansion, which had been almost entirely made up of converted hulls, the period after 1960 was characterized by the construction of ships designed for research: indeed. by the end of the period, conversions accounted for less than $20 \%$ of the fleet. On average, also, they were considerably larger, reflecting the trend of research interest away from the coastline and toward blue water. Finally, paralleling the growing dominance of federal support for marine research, over $80 \%$ of the new ships were acquired with federal funds.

An important sign of the maturing of academic oceanography was the formation in 1971 of the University-National Oceanographic Laboratory System (UNOLS), composed of all oceanographic institutions. Earlier, each institution had dealt with its federal supporters in isolation. and even collaboration among laboratories was minimal. There was no single voice speaking for the field. Ships were scheduled primarily for the use of scientists from the operating institution, and competition for funds was "cut-throat." Through UNOLS, consolidated scheduling of ships has greatly improved efficiency and assured availability of time at sea to all qualified researchers. A series of studies have looked at problems ranging from safety to instrumentation and from the need for new ships to their design. Through this association of ship operators, policies are recommended. and solutions to specific problems offered.

Unfortunately, toward the end of the 1960-80 period, the earlier enthusiasm for science waned: growth in oceanography tapered off in terms of uninflated dollars. Perhaps more importantly, the sources of federal funds changed dramatically. The Navy. which had almost single-handedly provided impetus and financial support for the post-war academic expansion. progressively lost interest. particularly in 
providing operational funds. NSF increasingly had to shoulder the costs both of research and ships. By the end of the period, it was paying for over threequarters of academic ship operations, including practically all the support for smaller vessels and for coastal oceanography. while the Navy's contribution dropped to about $15 \%$. Fortunately, this was partially offset by support from other government agencies. notably the Departments of Interior and Energy and the Environmental Protection Agency. primarily for specialized marine studies. For better or worse, by 1980 the academic fleet. by and large. had become an NSF show.

A broader result of the levelling-off in public interest. federal funds, and potential jobs was the stabilization of the academic community. Only a few new oceanographic institutions were established during this period. But the number of researchers had expanded greatly in the sixties and early seventies. and universities had relied on soft-money support for the oceanographic personnel and facilities more than in other sciences. Since NSF had become the major source of support for research as well as for ships. there was fierce competition for the nearly constant available funds. In spite of this, we may well look back on the years 1960-80 as the Golden Age of ocean science in the US: it was certainly a time of public concern, of growth, and of looking beyond our own territorial waters.

1980 to the Present

The final phase has continued the time of change and limitations in the national economy, coupled with overall restraint in funding for research. While many jobs for oceanographers developed during the period of strong growth. it is fair to say that the optimism of the 1960)s has not been fully realized. Due to the lack of expansion in universities and increasing research funding constraints. academic opportunities for many graduates of the 1970s have been limited. This has been exacerbated by similar reductions in federal programs outside the Navy and NSF, both in-house and in their support for academic scientists. Often, the capacity of the academic fleet has exceeded both research needs and support funds, and ships have had to be temporarily laid up.

Overall. it has been a time of accelerated application of oceanography to other fields. as well as a time when technology derived from space research. electronics and computer science has been put to use. A fundamental change stemming from these technologies has been the accuracy. and above all, the sheer volume of data collected at sea. A physical-chemical cruise now typically generates amounts of data two or three orders of magnitude larger than a comparable cruise of the 1950s. While this gives much greater productivity per ship-day, it has also created the need for facilities both at sea and ashore which can handle the load.

Another very significant change has been the planning, under NSF and Navy support. of largescale decadal global initiatives that would focus the work of many institutions and international consortia on major ocean problems. The World Ocean Circulation Experiment (WOCE) is one of the first of these. If funding is implemented, all will require deep-ocean vessels of long range and endurance, with large capacities for personnel, laboratories. and equipment. Within the existing academic fleet, only the Knorr and Melville and the planned Agors 23 and $2 t$ will be up to the task.

In sum, while the academic fleet of today is smaller than it was ten years ago, it is more productive, better equipped, and better-manned. All the "blue-water" ships are over 100 ' in length, and the majority are above $150^{\circ}$ '. reflecting the evolving need for bigger platforms with longer range, more science space, and better sea-keeping abilities (see Treadwell et al. , 1988, for a listing of modern ships). While they are more productive, they are also more expensive to operate. Since twenty-three of them. including practically all the larger ones, are supported in whole or large part by federal grants, continuing to find funds for them as well as for the embarked research will pose a difficult challenge for NSF, their major sponsor.

Finally, we note that the great majority of modern ships was built prior to 1975. Indeed, of the fortythree ships of all sizes which make up today's academic fleet, only twelve were built during the last deciade, and only four major ones. The present fleet has an average age of over fifteen years, and several ships are over a quarter-century old. The useful life of a research ship is reckoned at from twenty-five to thirty years. Thus. it is deeply disturbing that NSF has not built a new ship since 1981 and has none in its near-term plans. and that the Navy, once it finishes the two vessels now authorized. does not either. Given the lag-time from designing to budgeting to construction, and the difficulty of obtaining tens of millions of dollars in budget allocations, we feel that planning for the future of the academic fleet needs to be addressed as a matter of urgency.

\section{References}

Nelson. Stew art B., 1971: Oceanographuc Shus-Fore and Aft. Office of the Oceanographer of the Navy, U.S. Government Printing Office, Stock Number (08+2-(0)50. $240 \mathrm{pp}$.

Treadwell. T.K.. D.S. Gorsline and R. Went. 1988: Hestory of the L'S. Acudmic Occunowraphic Reseurth Fleet and the Soltrces of Rescarch Ships. UNOLS Flet Improvement Committee Report. I NOLS Fleet Improvement Committee Office. Texas A\&M University. $55 \mathrm{pp}$.
$W_{e}$

back on the years

$1960-80$ as the Golden

Age of ocean science

in the US. 